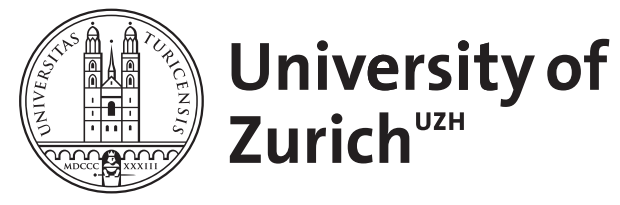

Zurich Open Repository and Archive

University of Zurich

University Library

Strickhofstrasse 39

CH-8057 Zurich

www.zora.uzh.ch

Year: 2002

\title{
What Variational Linguistics can learn from Galician
}

Kabatek, Johannes

Posted at the Zurich Open Repository and Archive, University of Zurich ZORA URL: https://doi.org/10.5167/uzh-85892

Journal Article

Originally published at:

Kabatek, Johannes (2002). What Variational Linguistics can learn from Galician. Estudios Sociolinguistica, 3,2(4,1):348-358. 


\section{Estudios de}

Sociolingüística Linguas, sociedades e. culturas

Volumes 3(2) 2002 \& 4(1) 2003

Separata 


\title{
What variational linguistics can learn from Galician
}

\author{
Johannes Kabatek \\ Universität Freiburg \\ Romanisches Seminar \\ Universität Freiburg \\ Werthmannplatz \\ D-79085 Freiburg im Brsg., Germany \\ kabatek@uni-freiburg.de
}

\section{Abstract}

This short overview reviews, in the first part, some of the most important fields of investigation where studies on Galician have contributed to variational linguistics, including macro- and micro-sociolinguistic studies (sections 1-3). The second part (sections 4-7) postulates some possible theoretical and empirical areas which we recommend to be included in future research. We propose a critical application of new models of linguistic vaich including recent frameworks such as studies on of nmaticalisation, OT, intonational phonogy, etc, but also call for the inction common in the European the ctrongly dynamic sitution of con. The high concentration of research intions for the theortical fran of constone for these theretical framewors, and Galician linguistics should apply them in a critical, flexible and creative way. This means that research on Galician will not only learn from theory but also contribute to it. We also briefly mention some of the areas where the studies of Galician have already contributed some important results to an overall perspective on Key wic variation.

Key words: variational linguistics, Galician, sociolinguistics, language change, sociology of language.

\section{Resumo}

Esta breve panorámica pasa revista, na súa primeira parte, a algúns dos máis importantes ámbitos de investigación nos que os estudios sobre o galego contribuíron á lingüística variacionista, incluindo estudios macro- e micro-sociolingüisticos (seccions 1-3). Na segunda parte (seccions 4-7) postulamos algunhas posibles areas teoricas e empiricas que recomendamos para que sexan incluidas en futuras investigacions. Proponemos unha aplicación critica de novos modelos de variación linguistica, incluíndo marcos recentes tales como os estudios sobre a gramaticalización, OT, fonoloxia entoativa, etc., pero tamén apelamos á inclusión de intuicions establecidas no estudio da variacion linguistica no seo da tradición europea. A alta concentración de institucións investigadoras e a situación fortemente dinámica do galego contemporáneo pode servir como unha pedra de toque 
empírica para eses marcos teóricos, e a lingüística galega debe aplicalos dun xeito crítico flexible e creativo. Isto significa que a investigación sobre o galego non aprenderá só da teoría senón que tamén contribuirá a facer teoría. Tamén mencionaremos brevemente algunhas das áreas en que os estudios sobre o galego xa produciron algúns resultados salientables de cara a unha perspectiva ampla sobre a variación lingüística.

Palabras clave: lingüística variacionista, galego, sociolingüistica, cambio lingüístico, socioloxía da lingua.

\section{Introduction}

"Variational linguistics" in the title of this paper refers to both the theory of language, a framework that may be applied to describe any linguistic situation in synchrony and diachrony, and it refers to generatities of variation and change understood as an open list of variation or change phenomena and possible historical constellations where they commonly occur. The difference between theory and generality is not a widely acknowledged one, and in most theoretical approaches theoretical principles and generalities are subsumed under the unique label of linguistic theory. However, there is a difference between a statement such as "linguistic convergence and divergence are the consequences of universal humain behaviour" and "a language with labial nasals will also have labial plosives", between axiomatic principles about the function of human language and statistical generalities based on experience with a large amount of empirical data. The former is a question of principal adequateness, whereas the latter is a matter of probability, even if the cases of $100 \%$ statistical evidence indicate frequently that there is a theoretical principle behind the observation. In fact, theory is an abstraction based on axiomatic principles and a certain number of $100 \%$-cases.

It seems obvious that what variational linguistics can learn from Galician will be, above all, a certain amount of empirical facts that may enlarge the list of possible "generalities". Contemporary Galician is a highly dynamic language in a wellstudied situation of contact with closely related Spanish; it allows for all kinds of variational research and already has been the object of a large number of important studies $^{1}$. And as in the case of Brazilian Portuguese, one of the Romance languages that has contributed the most to variational linguistics in the last decade, the quantity of new empirical data may also contribute to the theoretical discussion and seek an adequate theoretical framework; especially when there are further favouring external circumstances, which is the case here: contemporary Galician is an especially fertile field for new contributions to general linguistics due to a fortunate coincidence of

1 The list of Galician linguistic research is continually increasing. For an overview until the mid 90's see the bibliography compiled by Regueira Fernández in 1996; the updated database BILEGA can be consulted in the Internet under $<$ http://www.cirp.es $>$. three different factors: firstly, the political marginalisation of Galician during the Franco dictatorship led to an accumulation of pro-Galician forces which were able to profusely erupt after Franco's death in 1975 and shift Galician into the centre of ideological and also linguistic interest inside and outside Galicia; secondly, the social and economic changes of the last decades were echoed in a highly dynamic linguistic situation with directly observable ongoing linguistic changes; and thirdly, the contemporary economic situation has made the study of Galician attractive for local and foreign researchers due to well-equipped institutions and provisions for publication. Galician linguists presently have at their disposal several important research centres concentrated in a relatively small area that has been economically viable since the 80 's, in a prosperous region that can not only afford the acquisition of whatever information is needed but also is in direct contact with linguistic centres around the world. In matters of empirical studies, this means that Galician linguists have the resources to realize comprehensive projects, to form research groups and to apply the latest technology. In matters of theory, this provides the opportunity to combine the European tradition with contemporary innovations from Europe and overseas $^{2}$. The highly dynamic situation of contemporary Galician ${ }^{3}$ is an appropriate field for macro linguistic and micro linguistic, large-scale and short-term, quantitative and qualitative research, and all of these fields call for an overall theory of linguistic variation. In the following sections (2-3), I will first mention some of the areas where the linguistic "boom" in Galician in the last years has produced important results. Sections 4-6 will indicate some of the objectives upon which future investigation might concentrate.

\section{Some examples}

I will not try to summarise in a few lines the major achievements of the Galician "linguistic boom", but rather arbitrarily choose some examples where in my opinion the research on Galician has been or will be able to add some interesting aspects to general and variational linguistics. I will skip the isolated focus on 'internal' facts such as phonological, syntactic or morphological structures, but not without mentioning that there are several reasons why Galician here as well is an 'important' one among the Romance Languages. 'Archaic' on the one hand, and 'innovative' on the other, it is a key language: for understanding many of the central typological questions in the

$$
=
$$

2 However, the fact that most linguists play their individual parts in the ideologically controversial 2 However, the fact that most linguists play" their individual parts in the ideologically controversial
discussion about Galician language policies has the effect that contact among Galician linguists is sometimes characterized by ideological differences and lack of solidarity and collaboration, instead of a theoretical synthesis of different traditions, a rather dogmatic adoption of certain ideologies is often preferred.

3 See Kabatek (1997c) and, for an overview, Monteagudo \& Santamarina (1993). 
history of the Romance languages (above all, Iberoromance), a tertium comparationis in widely discussed cases such as the problem of the relationship between European and Brazilian Portuguese, the question of clitisation, the verbal systems of Iberoromance, its fundamental prosodic patterns, the question of the syntacticprosodic interface, etc., and it is also a key language for the recent discussions on creolisation in Romance. In the last years, studies on creolisation have turned to stress L2 acquisition processes ${ }^{4}$, against the traditional two hypotheses of African substrate and of L1 acquisition-simplification processes. Contemporary Galician allows us to observe - even if it is a particular situation of contact between closely related languages- how after a short period of intensive language mixture new stabilities are being created in a L2 acquisition process (speakers with Castilian as mother tongue use Galician, in fact an L2 for them, for everyday purposes; see Kabatek, 1998).

\section{Macro sociological studies}

One of the fields where the research on Galician has greatly contributed to a general view of linguistic variation is the study of the external development of speaker behaviour and attitudes from a quantitative perspective. A large number of macro sociological studies on the language situation in Galicia have been presented since the early seventies, and they allow a long-term comparison and the analysis of changing external factors such as the radical political turn after Franco's death and the impact of conscious language planning from the late seventies onwards. The first serious sociological study about the linguistic situation in Galicia was published in 1974 by the University of Seville ${ }^{5}$, with some surprising results in the light of future developments. In the 1980 s and 1990s, several studies on different domains have been presented ${ }^{6}$ and finally, the Mapa Sociolingüistico de Galicia, with results published from 1993 onwards ${ }^{7}$, has offered a complete panorama of the Galician speaker's attitudes based on an exhaustive collection of data. The studies differ methodologically, but they allow some observations on what happened after the conscious linguistic planning and the language policy since the 1980 s, with important institutional and financial help for the regional language. One of the surprising results of the 1974 study on attitudes in Galicia was that interviews with Galician people yielded a very high percentage of persons who described themselves as more attached to Galicia than to Spain (about $80 \%$; compared to $56 \%$ in the same type of question in Catalonia and $53 \%$ in the

4 See the summary of Sarah Julianne Robert's PhD Thesis on Hawaiian Creole at <http://www.stanford. edu/ sarahjr/propsummary.html>.

5 Ayestarán \& de la Cueva (1974).

6 See the list offered by Regueira Fernández (1996: 74-79)

7 The first pilot study was published in 1993 (Seminario de Sociolingüística da Real Academia Galega, 1993). Several exhaustive studies have followed.
Basque country). In general, they reported rather positive attitudes towards the regional language contrasting with the observable tendency toward language loss in younger generations, urban or semi-urban populations and higher classes. The positive attitudes should have been a fertile ground for an effective recovery of the regional language in a new political situation, but in fact aside from the evident tendency of parts of the urban middle-class to use Galician habitually and a strong presence in education and public usage, there seems not to have been an overall change in language use in Galicia ${ }^{8}$. Studies of the 1990's confirm the rather positive attitudes, but also a contrast between the attitudes and the real usage ${ }^{9}$. This means that one of the most outstanding results of a longer-term view of the Galician sociolinguistic situation is the relatively weak or only indirect effect of the language policy on linguistic behaviour, and there are two possible explanations for this. The easiest approach would be to simply conclude that the linguistic policy in the concrete case of Galicia has been rather ineffective, as can be heard frequently in everyday critics of the present situation. To give an example: in a recent study on attitudes of young Galician speakers aged between 17 and 22, in answer to the question concerning which of the two contact languages is being favoured by the local language policy, the response was "Spanish". almost as frequently as "Galician" 10 . If we consider that aside from the ideal of a "harmonious bilingualism"11, the official central aim of the language policy of the Galician institutions is to assure the survival of Galician (taking the survival of Spanish for granted), the result seems surprising. But a scientific analysis of the situation should go further and not be satisfied with a monocausal explanation. A second explication for the described lack of overall change, assuming that politics is, in Talleyrand's words, "the science of the possible", might also conclude that what is happening simply corresponds to the prestige-relationship currently existing in Galicia and that the relatively weak impact of the pro-Galician language policy is simply what could have been expected.

Reality seems to be somewhere between the two extreme interpretations, and maybe the moment has come for a detailed analysis of what has really happened

8 See Monteagudo (2000).

9 See e.g. Seminario de Sociolingüística da Real Academia Galega, 1993; 1995, 1996, and the 9 See e.g. Seminario de Sociolingũistica

10 Pantera (2002: 72). Twenty-three percent say that the language policy of the Galician government favours Galician, $16 \%$ say that Galician and Castilian are favoured in the same way, and $17 \%(!)$ say that the language favoured by the official linguistic policy is Spanish. The remaining $44 \%$ say they have "no opinion". The study was presented as a Master's thesis at the University of Frankfurt/Oder (Germany) and is based on interviews with 96 students from the area surrounding Vigo.

11 "Harmonous bilingualism" is frequently defined to be the aim of the Galician government's language policy. The term was the focus of the doctoral thesis of the former administration's director for language policy Manuel Regueiro Tenreiro, and is cited frequently by the president of the local government, Manuel Fraga Iribarne. 
during the past 30 years. The Galician government and the Galician language planners and sociolinguists should be extremely interested in such an analysis, where the political framework and the implementation processes of political decisions, on the one hand and the reaction of the speaker's population, on the other hand, should be compared, always distinguishing between the attitudes of the population and their behaviour. Such a detailed analysis, when compared to the other multilingual regions in Spain and several other "prototypical" cases of language planning outside the Iberoromance context, could provide helpful background information for the practice of language planning and for a general approach to what language planning really can achieve and where it reaches its limitations.

Here, macro sociolinguistic studies should also be supplemented by micro sociolinguistic case studies. For example, I have shown on several occasions how to the former diglossia between Galician and Castilian a new, inner-Galician diglossia is being added, where prestige forms of upper class or "educated" Galician contrast with the traditional dialects or with the mixtures between Castilian and Galician. However, the dynamic process of diaphasic differentiation of Galician is not uniform, and in many situations, the "old" diglossia is in conflict with the "new" one: middle class speakers who consciously have changed to Galician for everyday purposes can sometimes be "wrongly" identified as lower-class speakers by others who have not yet assumed the "new" scheme of inner-Galician diglossia. The whole complex process of diaphasic differentiation can best be studied through micro sociolinguistic detail studies which shed light on the sociolinguistic changes behind it.

\section{4. "Variational linguistics"}

"Variational linguistics" is an approach that was systematically introduced into linguistics some 50 years ago, and since the sixties, some linguistic schools have almost exclusively dedicated their work to this field. However, up to the present, the different schools have been rather isolated from each other and do not even concur in their conception of variation itself: variation is sometimes understood as a variation between linguistic systems, and in other cases as the coexistence and alternation, in one language, of isolated varying elements, or recently even as the variation in the ordering of grammatical constraints. In each case, the theoretical background is different, even if the phenomenon under discussion is the same.

In the European tradition, especially in Romance philology, variation is traditionally classified, according to the terminology of Leiv Flydal and Eugenio Coseriu, into three different dimensions, diatopic (dialectal) variation in space, diastratic variation in social groups and diaphasic variation in style ${ }^{12}$. This terminology was originally created in a structuralist tradition and referred to the fact

12 See Kabatek, 1994 that a structuralist view requires the isolation of discrete systems considered as syntopic, synstratic and synphasic units. Its original aim was not primarily the description of variation but rather the exclusion of it. In an overall view, variation cannot be limited to structures but must include structurally non-relevant elements (such as variation of allophonic variants) and the coexistence of varieties in a speaker's competence which lead to phonological and grammatical processes for the transformation of a form belonging to one variety into a form belonging to another. In the last few years, several scholars have amplified the coserian heritage and In the last few years, several scholars have amplified the coserian heritage
redefined variation from a pragmatic perspective on the speaker's performance ${ }^{13}$.

Maybe the internationally best-known theoretical approach in variational linguistics is the one of the Pennsylvania School, due to the continuous work of William Labov and his disciples. Some of the Pennsylvanian methods have been partly applied to Galician ${ }^{14}$, but; in general, the school has had few followers in Galicia. In the last years, some new theoretical and methodological approaches have been developed at this school, and it would be interesting to test them in the Galician case. Just an example: Anthony Kroch has presented, during the last years, a series of empirical studies where he criticizes the "wave-model" of linguistic change presented by Bailey (1973) (with predecessors in the history of linguistics), defending the idea that a linguistic change does not start in some salient cases and then shift slowly to the less salient ones, but that in fact different "contexts change together". Kroch argues, in a good Labovian tradition (Labov, 1975), with the methodological principle of using "the present to explain the past" 15 "and opposes. the "constant rate hypothesis" (Kroch, 1989: 201) to the wave model. One of the central observations in Kroch's work is a clear differentiation between surface phenomena and underlying grammatical systems (in plural!), which may produce fuzzy data at a first sight:

When surface forms change, the new usage reflects a change in the underlying grammar that licenses the forms, and incremental linguistic change seems often to reflect competition among alternative licensing principles for entire grammatical subsystems.

(Kroch, 1989: 239)

Galician is an interesting case to test this theoretical framework, for its highly dynamic situation offers easy access to different ongoing change processes. In my 1995 thesis $^{16}$, I have presented a number of examples of such ongoing changes, trying to offer a clear-cut difference between continuous change-processes and

13 In Kabatek, 1997b, an application to Galician can be found.

14 In Kabatek (2000: 97-142) a partly Labovian method, combined with a different theoretical frame14 In Kabatek (2000:

15 I have mentioned in several occasions that Labov first discovered this principle in his empirical work and then, after several years of application, discovered that it already was one of the central methodological principles of the Neogrammarian school at the end of the $19^{\text {th }}$ century (Kabatek, 2000: 91, n. 53). 16 Kabatek (1996; Galician version Kabatek, 2000) 
discrete units of linguistic competence. One of them was a certain extension of an alveolar nasal consonant and a reduction or even loss of the velar nasal in some urban speakers due to the influence of varieties of Spanish from outside of Galicia. Spanish in Galicia traditionally is a dialect strongly marked by Galician influence (see Monteagudo \& Santamarina, 1993) and has adopted more or less the distribution of the Galician nasal consonants. However, in the second half of the twentieth century, a standard Spanish pronunciation from the centre of the Peninsula has had increasing influence on certain urban varieties in Galicia. The corresponding "variety", if there is such, does not seem to be the most prestigious one and a further extension of the phenomenon is improbable, but this is not the theoretical problem. The problem consists of how to interpret the existence of almost all kinds of possible frequencies of the relationship between velar and alveolar pronunciation in utterances. One possibility would be to claim the continuous spreading of the phenomenon, according to the "wave model", from one context to another. But if we look closer at the data - and not only at quantitative statistics, but also at concrete instantiations - we see rather that we can assume the coexistence of several systems, manifested to different degrees by the individuals and actually mixed in concrete discourse situations. The main coexisting systems are a traditional Galician system, with velar nasals in word-final position and some isolated lexical items and with develarization of finals when a clitic is following. The other system would be "Castilian-like", with velar nasals only by assimilation through contact with velar consonants. We can even find that in some speakers' competence, between the two systems a third "interlanguage" exists, where nasal consonants are velar in certain lexical items and in final position, but where the develarization rule before a clitic is not present 17 . Further, we will find utterances corresponding to one of the three systems. But we will see, and this is the point, that in many cases the speaker's performance corresponds to more than one system, and that several systems can be mixed in discourse. A rule is an "intensive" regular fact in a grammar or system producing a "constant rate", whereas the extension of a phenomenon can be an isolated one attributed to a single lexical item or present in discourse due to interference with another system. This systematic difference between intensive and extensive generality is not a new one ${ }^{18}$, and the idea that several systems may be present in discourse has a long tradition in the European variationist discussion.

17 See Kabatek (2000: 147-51).There have been discussions about whether the rule that determines the alveolar pronounciation of $-n$ in non o fixo ("he/she hasn't done it") is a develarization rule or if the alveolar pronounciation is attributable to the fact that the clitic only apparently makes the $-n$ here stand in final position.

18 See Coseriu (1957), summarised in English in Coseriu (1983). Coseriu shows that the difference between both explains the difference between the Neogrammarian principle of the absoluteness of sound changes, referring to intensive generality, and the possibility of extensive generality of any fact which can determine the individual history of a single lexical item (cf. Malkiel, 1967).
If we go further and consider the factors that determine the selection of the one or the other form, it seems that the degree of planability of the discourse plays an important part. In a 1997 paper, I have tried to show that the criteria for selection correspond in some way to factors that Koch and Oesterreicher have called "language of distance" and "language of proximity", in fact universally definable degrees of elaboration of a text or discourse that allow for the speaker's more or less conscious intervention ${ }^{19}$. In a situation of co presence of several systems, the speaker, trying to realize a certain system corresponding to the actual discourse finality, will show different degrees of presence of elements belonging to other systems according to the degree of planability. The tension between several co present systems can also explain the well-known phenomenon of hypercorrection (Kabatek, 1997b: 230-33)

This interpretation is somehow the functional version of the different models of Variational Grammars offered in Generative linguistics since the late 1960 ' $\mathrm{s}^{20}$. Both traditions, clearly separated in the history of linguistics, could profit from a closer contact and the exchange of principles and methods, and Galician could offer an appropriate field for this kind of contact ${ }^{21}$

\section{Optimality Theory}

One of the theoretical frameworks most dominating the linguistic discussion of the last years is the recent Optimality Theory (Prince \& Smolensky; 1993; Kager, $1999)^{22}$ Being a universally oriented framework that tries to describe the differences between languages basically as a result of the different ordering of hierarchical, universal constraints, variation is already inherent in the fundamental principles of this theory. There have been attempts to describe variational phenomena within one language in terms of $\mathrm{OT}^{23}$ and there have also been some initial attempts to adop the OT-model for a description of certain Galician phenomena ${ }^{24}$. It would be an

19 See Koch \& Oesterreicher $(1985,1994)$

20 See e.g. Chomsky \& Halle (1968); Harris (1969), for Spanish. A very sophisticated critique of the limits of variational grammars, especially of the ones presented in studies on creoles, was offered by Weydt \& Schlieben-Lange (1981)

21 A fruitful contact of that kind has been established, in Brazil, in the work of the Campinas school of linguistics, above all in the publications of Fernando Tarallo and Mary Kato. See Roberts \& Kato (1993).

22 See exhaustive downloadable references at $<$ http://ruccs.rutgers.edu $>$.

23 For example, Paul Boersma, in his 1998 thesis, offers several chapters on variation, L2 acquisition and the constraint-based OT model. See Boersma (1998: 329-46), and particularly Boersma (1997). 24 See Colina (1997) and Holt (2000). However, an overarching variationist description of Galician within an OT framework has not yet been presented. 
interesting task for both the empirical description of Galician and a test of the theoretical value of the theory to attempt a comprehensive description of language variation in contemporary Galician in terms of OT, even if there may be some reservations about whether such a description is possible ${ }^{25}$.

\section{Grammaticalisation}

Another theoretical field where Galician could contribute clarifying results to a general discussion is the study of Grammaticalisation phenomena, one of the mainstreams in current linguistic research. Grammaticalisation, understood as a linguistic evolution where a lexical item becomes an element of Grammar or a grammatical item becomes "more grammatical" 26 , and where it is normally assumed that this process is irreversible, is generally observed, in several of the recent approaches, without taking into account the possible importance of linguistic variation. Linguistic variation seen, rather, as an exceptional, disturbing rather than a 'normal' fact, as Ramat \& Hopper (1998: 7) point out; they distinguish 'normal changes' from 'exceptional' ones, the latter 'disturbed' by 'external factors' such as linguistic variation in the case of Creoles:

we are faced with the impact of substrate languages, which in the history of creoles represent an external factor and a source of changes which may interfere with norma 'natural' changes.

Ramat \& Hopper, 1998: 7)

Nevertheless, the coexistence of languages and varieties is by no way an exception: it is rather the rule, and linguistic research throughout the twentieth century has subsequently tried to assume it in certain schools, but it is still being passed over in others, as in most of the works of the generative tradition. The most important achievements of the studies of grammaticalisation are the determination of cross-linguistically preferred processes of lexical items becoming grammatical forms, and a large-scale view of certain processes of language change. However, in 25 Several variation phenomena can easily be described in terms of OT, as lack of assimilations in
elaborated speech vs. assimilation in casual speech can be interpreted as change of constraint hierarchy. elaborated speech vs. assimilation in casual speech can be interpreted as change of constraint hierarchy. However, it is more difficult to describe variation in cases where there are probably different underlying
inputs (like between two languages as Galician and Castilian), and it seems problematic to explain the inputs (like between two languages as Galician and Castilian), and it seems problematic to explain the
phenomenon of hypercorrection, where it is not re-ordering of rules but correspondence-rules between phenomenon of hypercorrection, where it is not re-ordering
different inputs that seem to be responsible for the output.

26 As in Kurylowicz' definition: "Grammaticalization consists in the increase of range of a morpheme advancing from a lexical to a grammatical or from a less grammatical to a more grammatical status, e.g. from a derivative formant to an inflectional one" (Kurylowicz, 1965: 69). See Lehmann (1985), Hopper \& Traugott (1993), for a general introduction. two ways grammaticalisation theory is reverting to the linguistics of the $19^{\text {th }}$ the function of the elements under study in the respective linguistic systems and, on the other hand, when a view on language is presented as if it were a homogeneous organism evolving only throughout time. There have been exhaustive discussions on whether grammaticalisation can be interrupted or even reversed. In many of the approaches to grammaticalisation the logical answer to this question must be "no", but this is in fact due to a partial view of linguistic reality. An element such as the Latin habere, once it has become a future morpheme in the Romance languages, has lost its original form and function, and there is logically no imaginable way back from the element i in that a simplistic view of language is offered, where linguistic change is considered to that a simplistic view of language is offered, where linguistic change is considered to
be the transition from one Saussurien état de langue $A$ to another état de langue $B$, and so on, without the possibility of coexisting systems.

Table 1. Supposed evolution of language.

\begin{tabular}{|l|l|l|l|}
\hline & Stage 1 & Stage 2 & Stage 3 \\
\hline Stage of language & $\mathrm{A} \longrightarrow$ & $\mathrm{B} \longrightarrow$ & $\mathrm{C} \longrightarrow[\ldots]$ \\
\hline
\end{tabular}

If, on the contrary, we assume coexisting languages in the same community, and different states of language known to the same speaker, we can frequently observe that evolution can 'go back", not because one state of a language would 'remember' a former one, but because of its not being isolated. If we consider the Galician recovery former one, but because of its not being isolated. If we consider the Galician recovery
of the inflected infinitive (see Kabatek, 1997a), we can see that this element seemed completely lost in certain urban or semi-urban varieties ${ }^{27}$. In the last few years, we can observe a recovery of the form, not only in written texts, but even in spoken urban discourse We have, thus, an evolution of a more complicated sort:

Table 2. Evolution of inflected infinitives with relation to varieties.

\begin{tabular}{|l|l|l|l|}
\hline & Stage 1 & Stage 2 & Stage 3. \\
\hline Variety 1 (urban) & + infl. inf. $\longrightarrow$ & -infl. inf. $\longrightarrow$ & +infl. inf. \\
\hline Variety 2 (rural) & +infl. inf. $\longrightarrow$ & +infl. inf. $\longrightarrow$ & +infl. inf. \\
\hline
\end{tabular}

27 See Gondar (1978: 155) 
The explanation of the historical 'recovery' of inflected infinitives in variety 1 does not lie in a remembrance of the diachronically lost state 1 , but in an adoptioty 1 this form from a variety where it has continually existed. Urban Galician is not an isolated variety, and due to certain necessities of the speakers and to a high prestige of Galician autochthonous forms, the elder form is adopted from a coexisting dialect, reintroducing something 'lost' in Variety 1. Such a reintroduction can be effected by adopting elements from other dialects, but also by reactivating elements conserved in written texts ${ }^{28}$. Grammaticalisation, in this variationist view, might be 'interrupted' or 'reversed', not because of a real 'going back' of the evolution but as a result of the adoption of a lost element from another variety or language. This means, on the other hand, that grammaticalisation can also 'skip' some of the stages for the same reason, which seems to be happening in some cases of introduction of the periphrastic perfect into certain varieties of Galician as an adoption from Castilian, skipping some of the steps of the inner-Castilian grammaticalisation process and directly adopting the current stage. Rather than a linear development we should thus prefer a variationist view, where almost 'anything is possible'. However -and this is why large-scale research strongly confirms grammaticalisation tendencies - the general shift of all varieties might predominantly follow the direction of a certain cognitive path, but the exceptions in the evolution of this abstraction may only be explained by a detailed view of the single processes ${ }^{29}$.

Contemporary Galician shows a series of processes of "reversed grammaticalisation" especially in purist Neo-Galician urban varieties, where the evolution of the whole verbal and clitic system is being reversed as a reaction to the secular influence of the contact language - and partly as a "negative" contemporary influence of this language ${ }^{30}$ elements historically adopted into Galician from Spanish are now being rejected in order to 'purify' Galician.

\section{Conclusions}

The co presence, on the one hand, of the European tradition of variationism which departs from a structuralist view of language systems, and on the other hand frameworks like Cognitive Grammar, Grammaticalisation theory, OT or

28 This has always been known in the case of so-called learned words or "cultismos" adopted from the written tradition, but it can also happen with elements of grammar. Consider the old Spanish pluperfect suffix -ra (amara), conserved only in poetry and certain written text types and recovered in pluperfect in peninsular Spanish journalist's usage even in spoken discourse (see Dietrich, 1981). 29 This is why a metaphor such as the "civisible ba d", so much in fas change in past years, is by no mas linguistic change in past years, is by no means an explanation but rather only a good metaphor for an abstraction

30 See Kabatek (2000) for further discussion.
Pennsylvania-style variation theory could lead, with reference to the empirical object of contemporary Galician, to a synthesis that would enrich the linguistic discussion not only by some contributing new empirical data and new "generalities", but also by providing at least some steps towards an innovative theoretical framework for the description of linguistic variation.

I have only presented some short impressions about a series of fields where the highly dynamic empirical evolution of Galician in combination with the local linguistic tradition can furnish important contributions toward expanding general knowledge of variational linguistic phenomena and of the theory of variation. One of the most important conditions necessary to make this really happen is scientific contact and communication. Galicia has created its own centres of research in the last years, but as important as the creation of local research activities are the input from other centres and schools. There should be more personal contact between the international and local Galician linguistic centres, more Galician researchers studying abroad and more researchers from abroad studying the rich empirical reality in Galicia. Galician linguistics can still learn a lot from the differen international approaches to variational linguistics, and variational linguistics will learn, in turn, from the Galician reality.

\section{Bibliographical references}

Ayestarán Aranaz, M \& A. Justo de la Cueva (1974). Las familias de la provincia de Pontevedra en 1974. Galleguidad y conflicto lingüistico gallego. Sevilla: Instituto de Ciencias de la Familia.

Bailey, C.-J. (1973). Variation and Linguistic Theory. Washington, D.C.: Center for Applied Linguistics.

Boersma P (1997). Functional Phonology. Formalizing the Interactions between Articulatory and Perceptual Drives. Ph.D. Thesis, University of Amsterdam.

Boersma, P. (1998). "How we learn variation, optionality and probability". Proceeding. of the Institute of Phonetic Sciences of the University of Amsterdam 21, 59-90 [Rutgers Optimality Archive $<$ http://ruccs.rutgers.edu/roa.html $>$ ]

Bröking, A. (2002). Sprachdynamik in Galicien. Untersuchungen zur sprachlichen Variation in Spaniens Nordwesten. Tübingen: Narr.

Chomksy, N. \& M. Halle (1968). The Sound Patterns of English. New York, Evanston \& London: Harper \& Row.

Colina S. (1997) "Epenthesis and Deletion in Galician: An Optimality Theoretic Approach". In F. Martínez-Gil \& A. Morales-Front (eds.), Issues in the Phonology and Morphology of the Major Iberian Languages: Washington D.C.: Georgetown University Press, 235-67.

Coseriu, E (1978). Sincronia, diacronia e historia. El problema del cambio lingüístico. Madrid: Gredos [ $3^{\mathrm{a}}$ ed.; $1^{\mathrm{a}}$ ed. Montevideo, 1957]. 

Coseriu, E. (1983). "Linguistic Change does not exist". Linguistica Nuova ed Antica
1, 51-63.

Dietrich, Wolf (1981). "Zur Funktion der spanischen Verbform auf-ra", Romanistisches Jahrbuch 32, 247-59.

Gondar, Francisco G. (1978). O infinitivo conxugado en galego. (=Verba, Anuario Galego de Filoloxia. Anexo 13). Santiago de Compostela: Universidade de Santiago.

Harris, J.W. (1969). Spanish Phonology. Cambridge, MA: MIT.

Holt, D.E. (2000). "Comparative Optimality-Theoretic Dialectology: Singular/Plural Nasal Alternations in Galician, Mirandese (Leonese) and Spanish". In H. Campos, E. Herburger, A. Morales-Front \& T.J. Walsh (eds.), Hispanic Linguistics at the Turn of Millenium: Papers from the 3rd Hispanic Linguistic Symposium. Sommerville, MA: Cascadilla, 125-43.

Hopper, P.J. \& E.C. Traugott (1993). Grammaticalization. Cambridge: Cambridge University Press.

Iglesias, A. (1999): "Os estudios empíricos sobre a situación sociolingüística do galego". Cadernos de Lingua 19, 5-42.

Kabatek, J. (1994) "Variedades lingüísticas e competencia comunicativa". Cadernos de Lingua 10, 7-18.

Kabatek, J. (1996). Die Sprecher als Linguisten. Interferenz- und Sprachwandelphänomene dargestellt am Galicischen der Gegenwart. Tübingen: Niemeyer.

Kabatek, J. (1997a). "Strengthening identity: differentiation and change in contemporary Galician". In J. Cheshire \& D. Stein (eds.), Taming the Vernacular. From Dialect to Written Standard Language. London \& New Vernacular. From Dialect

Kabatek, J. (1997b). "Dime cómo hablas y te diré quién eres. Mezcla de lenguas y posicionamiento social". Revista de Antropología Social 6, 215-36.

Kabatek, J. (1997c):“The Koineization process of contemporary Galician as a field for the study of language change". In B. Fernández Salgado (ed.) Proceedings of the 4th International Conference on Galician Studies, Vol. I. Oxford: Oxford Centre for Galician Studies, 163-78.

Kabatek, J. (1998). "The mother tongue as second language: strategies of linguistic integration". In J.M. Oro Cabanas \& J. Varela Zapata (eds.), Diálogo de culturas. Santiago de Compostela: Universidade de Santiago, 57-70

Kabatek, J. (2000). Os falantes como lingüistas. Tradición, innovación $e$ interferencias no galego actual. Vigo: Xerais.

Kager, R. (1999). Optimality Theory. Cambridge University Press.

Koch, P. \& W. Oesterreicher (1985). "Sprache der Nähe - Sprache der Distanz. Mündlichkeit und Schriftlichkeit im Spannungsfeld von Sprachtheorie und Sprachgeschichte". Romanistisches Jahrbuch 36, 15-43.
Koch, P. \& W. Oesterreicher (1994). "Schriftlichkeit und Sprache". In H. Günther \& O. Ludwig (eds.) (1994-96). Schrift und Schriftlichkeit. Ein internationales Handbuch / Writing and its Use. An international Handbook, Vol. 1. Berlin \& New York: De Gruyter, 587-604.

Kroch, A. (1989). "Reflexes of grammar in patterns of language change". Language Variation and Change 1, 199-244.

Kroch, A. (1995). "Dialect and style in the speech of uppper class Philadelphia". In G.R. Guy, J. Baugh, D. Schiffrin \& C. Feagin (eds.), Towards a Social Science of Language. Papers in Honor of William Labov, Vol. 1. Philadelphia: John Benjamins, 23-46.

Kurylowicz, J. (1965). "The evolution of grammatical categories". Diogenes 51, 55-

Labov, W. (1975): "The use of the present to explain the past". In L. Heilmann (ed.), Proceedings of the $11^{\text {th }}$ International Congress of Linguistics. Bologna: Il Mulino, 825-51.

Lehmann, C. (1985). "Grammaticalization: Synchronic variation and diachronic change". Lingua e Stile 20, 303-18.

Malkiel, Y. (1967). "Each word has a history of its own". Glossa 1(2), 137-49.

Monteagudo, H. (2000). "Quinze ans de la Loi de Normalisation Linguistique en Galice (1983-1998): Notes pour un bilan". Lengas 47, 131-57.

Monteagudo, H. \& A. Santamarina (1993). "Galician and Castilian in contact: historical, social and linguistic aspects". In R. Posner \& JN. Green (eds.) Trends in Romance Linguistics and Philology, vol. 5: Bilingualism and Linguistic Conflict in Romance. Berlin \& New York: Mouton de Gruyter, $117-73$.

Pantera, A. (2002). Das Sprachbewusstsein galicischer Jugendlicher. Unpublished diploma thesis, Frankfurt/Oder, Viadrina University.

Prince, A. \& P. Smolensky (1993). Optimality Theory: Constraint Interaction in Gerenative Grammar. Piscataway: Rutgers University.

Ramat, A.G. \& P.J. Hopper (1998). The Limits of Grammaticalization. Amsterdam \& Philadelphia: John Benjamins.

Regueira Fernández, X:L. (ed.) (1996). Guía bibliográfica de lingüística galega. Vigo: Xerais.

Roberts, I. \& M. Kato (1993). Português Brasileiro. Uma viagem diacrônica. Campinas: Editora da Unicamp.

Seminario de Sociolingüística da Real Academia Galega (1993). Estudio sociolingüistico da comarca ferrolá (= Cadernos de Lingua. Anexo 1). A Coruña: Real Academia Galega. [Previous study to the Mapa Sociolingüístico de Galicia.]

Seminario de Sociolingüística da Real Academia Galega (1995). Usos lingüísticos en Galicia (Mapa sociolingüistico de Galicia, Vol. II). A Coruña: Real 
Academia Galega. [Coordinated by M. Fernández Rodríguez \& M.A. Rodríguez Neira.]

Seminario de Sociolingüística da Real Academia Galega (1996) Actitudes

lingüisticas en Galicia (Mapa sociolingüistico de Galicia, Vol. III). A Coruña: Real Academia Galega. [Coordinated by Mauro Fernández Rodríguez \& M.A. Rodríguez Neira.]

Weydt, H. \& B. Schlieben-Lange (1981). "Wie realistisch sind Variationsgrammatiken?". In H. Geckeler et al. (eds.), Logos Semantikos. Studia inguistica in honorem Eugenio Coseriu, Bol. V. Madrid, Berlin \& New York: Gredos \& Mouton de Gruyter, 117-45. 